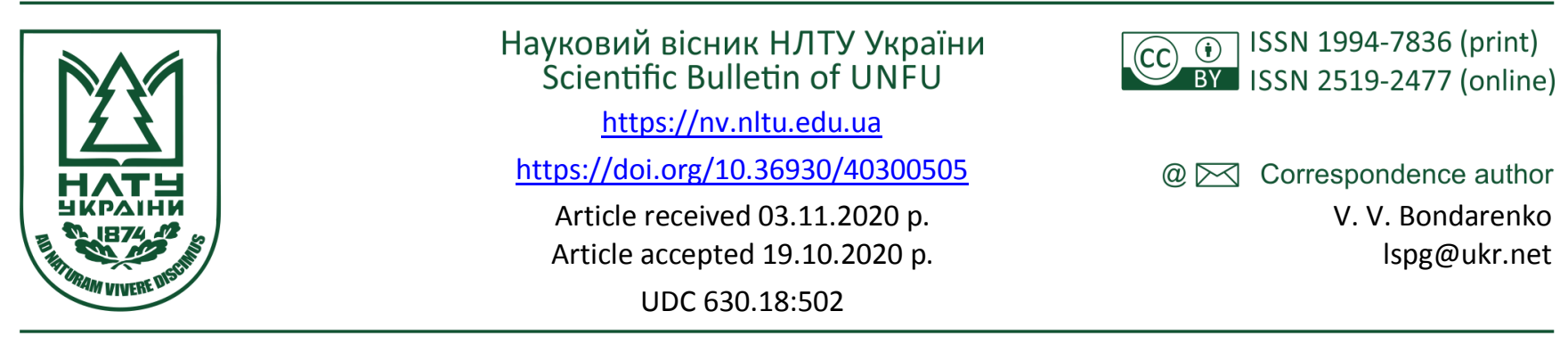

С. І. Мусієнко, В. А. Лук'янець, В. В. Бондаренко, М. Г. Румянцев, О. В. Кобець

Украӥнський ордена "Знак пошани" науково-дослідний інститут лісового господарства і агролісомеліорації ім. Г. М. Висоцького, м. Харків, Україна

\title{
ТИПОЛОГІЧНЕ РІЗНОМАНІТТЯ РЕКРЕАЦІЙНО-ОЗДОРОВЧИХ ЛІСІВ ЛІВОБЕРЕЖНОЇ УКРАЇНИ
}

\begin{abstract}
Вивчено типологічне різноманіття рекреаційно-оздоровчих лісів Лівобережної України за природними зонами: Лівобережне Полісся; Лівобережний Лісостеп та Лівобережний Степ. Досліджено різноманіття типів умов місцезростання рекреаційно-оздоровчих лісів залежно від їх розташування: у межах міст, селищ та інших населених пунктів; у межах округів санітарної охорони лікувально-оздоровчих територій і курортів; у межах поясів зон санітарної охорони водних об'єктів у лісах; зелених зон навколо населених пунктів; поза межами лісів зелених зон. Встановлено, що для рекреаційно-оздоровчих лісів Лівобережної України характерна вся широта як трофогенного, так і гігрогенного рядів. Найбільша частка площі та запасу насаджень зосереджена в умовах дібров, а найменша - в умовах борів. Найбільше значення середнього запасу на 1 га відзначено в умовах суборів, а найменше - в умовах дібров. Серед гігротопів панівне становище займають насадження, що ростуть в свіжих умовах. Незначною є частка насаджень, що ростуть в дуже сухих умовах. Визначено, що більшість насаджень в рекреаційно-оздоровчих лісах ростуть в умовах свіжих грудів. У Лівобережному Поліссі переважають борові умови за трофністю і свіжі - за зволоженням. У Лівобережному Лісостепу найбільші площі займають лісові ділянки в умовах свіжих грудів. Насадження Лівобережного Степу ростуть переважно на багатих та зволожених грунтах. Ці особливості потрібно врахувати під час планування та здійснення відповідних лісогосподарських заходів, спрямованих на вирощування високопродуктивних, стійких, довговічних і високодекоративних насаджень, які ефективно виконуватимуть важливі еколого-захисні функції. Перспективним залишається питання щодо збільшення видового різноманіття в рекреаційно-оздоровчих лісах Лівобережної України, зокрема за рахунок інтродукованих деревних та чагарникових видів, для підвищення їхніх екологічних та естетичних властивостей.
\end{abstract}

Ключові слова: насадження; лісові ділянки; природні зони; тип умов місцезростання; трофотоп; гігротоп.

\section{Вступ}

Раціональне використання природних ресурсів за умов інтенсивного розвитку промисловості, транспорту, сільського господарства, використання людством щораз більшої кількості природних ресурсів - важлива проблема сучасності, від правильного вирішення якої залежить не тільки збереження природних багатств i підтримання екологічної рівноваги, але й благополуччя нинішнього та майбутнього поколінь людей [2].

Рекреаційні ресурси - це частина природних ресурсів, що забезпечує відпочинок як засіб відновлення i підтримання працездатності й здоров'я людини. Зважаючи на велике оздоровче значення лісів, створено спеціальні території для відпочинку: паркові масиви, лісо- парки, зелені зони відпочинку тощо, тому роль рекреаційно-оздоровчих лісів усіх країн світу з кожним роком зростає. На сьогодні питання, пов'язані з рекреаційно-оздоровчими лісами, порушують багато вчених і практиків у країнах Свропи та Північної Америки [4].

Об'єкт досліджень - рекреаційно-оздоровчі ліси.

Предмет досліджень - методи і засоби визначення едатопічного різноманіття рекреаційно-оздоровчих лісів Лівобережної України.

Мета роботи - вивчення екологічного різноманіття рекреаційно-оздоровчих лісів Лівобережної України за природними зонами та залежно від їх розташування (підкатегорій).

Для досягнення зазначеної мети визначено такі ос-

\section{Інформація про авторів:}

Мусієнко Сергій Іванович, канд. с.-г. наук, ст. наук. співробітник, лабораторія лісівництва. Email: musienkosergij_les@ukr.net; https://orcid.org/0000-0002-6581-2670

Лук'янець Володимир Антонович, ст. наук. співробітник, лабораторія лісівництва. Email: lukyanetc@uriffm.org.ua; https://orcid.org/0000-0002-3427-4240

Бондаренко Віра Володимирівна, мол. наук. співробітник, лабораторія лісівництва. Email: Ispg@ukr.net; https://orcid.org/0000-0001-8187-5519

Румянцев Максим Григорович, канд. с.-г. наук, ст. наук. співробітник, лабораторія лісових культур та агролісомеліораці. Email: maxrum-89@ukr.net; https://orcid.org/0000-0002-2245-2441

Кобець Олексій Володимирович, канд. с.-г. наук, ст. наук. співробітник, лабораторія лісівництва. Email: alexei_kobec@ukr.net; https://orcid.org/0000-0003-0712-8827

Цитування за ДстУ: Мусієнко С. І., Лук'янець В. А., Бондаренко В. В., Румянцев М. Г., Кобець О. В. Типологічне різноманіття рекреаційно-оздоровчих лісів Лівобережної України. Науковий вісник НЛтУ України. 2020, т. 30, № 5. С. 31-35.

Citation APA: Musienko, S. I., Lukyanets, V. A., Bondarenko, V. V., Rumiantsev, M. H., \& Kobets, O. V. (2020). Typological diversity of recreational and health-improving forests in Left-Bank Ukraine. Scientific Bulletin of UNFU, 30(5), 31-35. https://doi.org/10.36930/40300505 
новні завдання дослідження: встановлення панівних трофотопів та гігротопів у рекреаційно-оздоровчих лісах Лівобережної України за природними зонами та залежно від їх розташування (підкатегорій).

Наукова новизна отриманих результатів дослідження - вперше досліджено типологічне різноманіття рекреаційно-оздоровчих лісів Лівобережної України за природними зонами та залежно від їх розташування (підкатегорій)

Практична значущість результатів дослідження отримані результати $є$ основою для планування в подальшому лісогосподарських заходів, спрямованих на вирощування високопродуктивних, стійких, довговічних і високодекоративних насаджень, які ефективно виконуватимуть важливі еколого-захисні функції.

Матеріали та методи дослідження. Матеріали останнього лісовпорядкування (повидільна база даних ВО "Укрдержліспроект") були основою для виконання розрахунків. Загалом проаналізували понад 143 тис. таксаційних виділів насаджень, віднесених до рекреаційно-оздоровчих лісів, у межах Лівобережної України. Площа досліджуваних насаджень становила 483208 га.

Охоплено лісовий фонд насаджень 84 державних підприємств лісового господарства в межах 11 адміністративних областей (Дніпропетровська, Донецька, Запорізька, Київська, Луганська, Полтавська, Сумська, Харківська, Херсонська, Черкаська та Чернігівська області). Територіально Дніпропетровську, Донецьку, Запорізьку, Луганську, частина Харківської та Херсонську області віднесено до Лівобережного Степу; частину Київської, Полтавську, частини Сумської, Харківської, Черкаської та Чернігівської областей - до Лівобережного Лісостепу; частини Київської, Сумської та Чернігівську області - до Лівобережного Полісся.

Аналіз останніх досліджень та публікацій. Ліси України за своїм призначенням і місцем розташування виконують переважно екологічні (водоохоронні, захисні, санітарно-гігієнічні, оздоровчі та інші) функції і мають обмежене експлуатаційне значення [1].

До рекреаційно-оздоровчих лісів належать лісові ділянки, що виконують рекреаційну, санітарно-гігієнічну та оздоровчу функцію, використовуються для туризму, занять спортом, санаторно-курортного лікування та відпочинку населення і розташовані:

- у межах міст, селищ та інших населених пунктів;

- у межах округів санітарної охорони лікувально-оздоровчих територій і курортів;

- у межах поясів зон санітарної охорони водних об'єктів у лісах;

- зелених зон навколо населених пунктів;

- поза межами лісів зелених зон [5, 8].

Розроблення чітких принципів типології лісових угруповань $є$ необхідною передумовою для організації найбільш раціональних заходів зі створення лісів, догляду за ними і захисту їх від різних несприятливих факторів [3].

На аналізі фактів трапляння і відсутності рослин в окремих ланках екологічних рядів грунтується методика порівняльної екології. Порівняльно-екологічна оцінка типів умов місцезростання за рослинами-індикаторами $€$ найзручнішою, оскільки вона, ігноруючи рамки ценозів, дає точніше висвітлення умов середовища i змушує звертати увагу на їх зміни. При цьому, кожний рослинний вид і екотип є складною єдністю, що реагує на всі умови місцезростання. Найціннішими індикато- рами, що максимально синтетично свідчать про клімат, трофність і зволоження грунтів, є деревні породи. Так, наприклад, наявність у складі насаджень сосни звичайної (Pinus sylvestris L.) свідчить про бідні, а ясена звичайного (Fraxinus excelsior L.) - про багаті грунти; модрини європейської (Larix decidua Mill.) про холодний клімат, вільхи чорної (Alnus glutinosa L.) - про дуже вологі грунти тощо $[6,7,9]$.

\section{Результати дослідження та їх обговорення}

Рекреаційно-оздоровчі ліси Лівобережної Україні зосереджені у трьох лісорослинних зонах (Полісся, Лісостеп, Степ) і загалом ростуть на площі 483208 га, зокрема в Поліссі - на площі 61943,8 га, у Лісостепу - на площі 209302,0 га, у Степу - на площі 211962,2 га (табл. 1). Серед рекреаційно-оздоровчих лісів Лівобережної України найбільша площа насаджень зосереджена в умовах дібров - 198000,4 га. У дібровах зосереджено і найбільший загальний запас $-42297,4$ тис. ${ }^{3}$. Найменша площа насаджень зосереджена в умовах борів $-64767,0$ га із запасом - 14444,8 тис. м ${ }^{3}$. Субори та судіброви займають проміжні значення як за площею 125987,3 та 94453,3 га відповідно, так і за загальним запасом - 37125,4 та 17932,3 тис. м³. Щодо запасу на 1 га насаджень, то найбільшого значення він досягає в умовах суборів - $295 \mathrm{~m}^{3}$, а найменшого в умовах сугрудів $214 \mathrm{~m}^{3}$. Серед гігротопів панівне становище займають насадження у свіжих умовах: у борах $-10,3 \%$; у суборах $-21,7 \%$; у сугрудах $-8,3 \%$; у грудах $-26,7 \%$. Дуже мало насаджень займають площі з дуже сухими гігротопами.

Аналізуючи рекреаційно-оздоровчі ліси Лівобережного Полісся зазначимо, що як за площею, так і за загальним запасом, переважають насадження в умовах суборів - 55,6 і 60,0 \%, а найменше росте насаджень в умовах груд - 1,0 і 0,8 \% відповідно. Найбільшого значення запас насаджень досягає в умовах суборів $327 \mathrm{~m}^{3} \cdot \mathrm{ra}^{-1}$, а найменшого в умовах груд $-248 \mathrm{~m}^{3} \cdot \mathrm{ra}^{-1}$. За зволоженням переважають лісові ділянки зі свіжим типом: у борах - 21,1\%; у суборах - 45,3\%; у сугрудах $7,8 \%$; у грудах - 0,3\%. В дуже сухих і сухих умовах Лівобережного Полісся насадження майже відсутні.

Переважаюча частина насаджень Лівобережного Лісостепу ростуть в умовах груд - 55,6 \% маючи при цьому 52,0 \% всього загального запасу в цій природній зоні. Найменше насаджень зосереджено в борах - 6,9\% iз запасом - 3684,2 тис. м $^{3}$, що становить $6,6 \%$ загального запасу. Найбільшого значення запас сягає в умовах борів - $321 \mathrm{~m}^{3} \cdot \mathrm{ra}^{-1}$, а найменшого в умовах груд $247 \mathrm{~m}^{3} \cdot \mathrm{ra}^{-1}$. Свіжі гігротопи займають панівне становище серед лісових ділянок в умовах борів - 5,6 \%; суборів - 20,3\%; сугруд - 11,1\%; груд - 46,9\%. Частка насаджень в дуже сухих умовах становить $<0,1 \%$.

Насадження Лівобережного Степу ростуть переважно в умовах груд - 38,1 \%. Вони також характеризуються найбільшим загальним запасом - 35,6 \%. Найменшу площу займають насадження в умовах борів - $17 \%$, а найменший загальний запас насаджень зосереджений в сугрудах - $16 \%$. Деревостани в умовах борів мають найбільший запас $-246 \mathrm{~m}^{3} \cdot \mathrm{ra}^{-1}$, а найменший в сугрудах - $124 \mathrm{~m}^{3} \cdot \mathrm{ra}^{-1}$. Щодо зволоження, то тут переважають лісові ділянки у свіжих умовах: у борах $-11,8 \%$; суборах - $16,3 \%$; сугрудах $-5,1 \%$; грудах - $14,9 \%$, а найменшу площу займають насадження в дуже мокрих умовах, що $€$ закономірним для цієї природної зони. 
Табл. 1. Розподіл рекреаційно-оздоровчих лісів Лівобережної України за природними зонами та типами умов місцезростання

\begin{tabular}{|c|c|c|c|c|c|c|c|c|c|}
\hline \multirow{3}{*}{ ТУМ } & \multicolumn{2}{|c|}{ Полісся } & \multicolumn{2}{|c|}{ Лісостеп } & \multicolumn{2}{|c|}{ Степ } & \multicolumn{3}{|c|}{ Разом } \\
\hline & \multirow{2}{*}{ площа, га } & \multirow{2}{*}{ запас, тис. м $^{3}$} & \multirow{2}{*}{ площа, га } & \multirow{2}{*}{ запас, тис. м $^{3}$} & \multirow{2}{*}{ площа, га } & \multirow{2}{*}{ запас, тис. ${ }^{3}$} & \multirow{2}{*}{ площа, га } & \multicolumn{2}{|c|}{ запас } \\
\hline & & & & & & & & тис. $\mathrm{m}^{3}$ & $\mathrm{~m}^{3} \cdot \mathrm{ra}^{-1}$ \\
\hline $\mathrm{A}_{0}$ & 2,4 & 0,3 & 21,1 & 2,4 & 160,4 & 18,7 & 183,9 & 21,4 & 116 \\
\hline $\mathrm{A}_{1}$ & 1091,8 & 211,3 & 2675,0 & 556,2 & 10674,9 & 1517,3 & 14442,7 & 2284,8 & 158 \\
\hline $\mathrm{A}_{2}$ & 13082,7 & 3738,2 & 11626,7 & 3125,5 & 25049,8 & 5229,3 & 49759,2 & 12093,0 & 243 \\
\hline $\mathrm{A}_{3}$ & 126,2 & 25,0 & 1,0 & 0,1 & 252,6 & 20,4 & 379,8 & 45,5 & 120 \\
\hline $\mathrm{A}_{4}$ & 1,4 & 0,1 & - & - & - & - & 1,4 & 0,1 & 71 \\
\hline Разом & 14304,5 & 3974,9 & 14324,8 & 3684,2 & 36137,7 & 6785,7 & 64767,0 & 14444,8 & 223 \\
\hline $\mathrm{B}_{0}$ & - & - & - & - & 59,8 & 3,3 & 59,8 & 3,3 & 55 \\
\hline $\mathrm{B}_{1}$ & 3,8 & 0,8 & 886,9 & 229,9 & 8936,9 & 1888,6 & 9827,6 & 2119,3 & 216 \\
\hline $\mathrm{B}_{2}$ & 28091,5 & 9765,8 & 42465,1 & 13820,0 & 34529,8 & 9108,7 & 105086,4 & 32694,5 & 311 \\
\hline $\mathrm{B}_{3}$ & 6037,3 & 1445,2 & 1309,4 & 297,2 & 3125,4 & 487,4 & 10472,1 & 2229,8 & 213 \\
\hline $\mathrm{B}_{4}$ & 284,7 & 38,9 & 168,7 & 27,8 & 53,1 & 6,9 & 506,5 & 73,6 & 145 \\
\hline $\mathrm{B}_{5}$ & 28,4 & 4,1 & 5,2 & 0,5 & 1,3 & 0,3 & 34,9 & 4,9 & 140 \\
\hline Разом & 34445,7 & 11254,8 & 44835,3 & 14375,4 & 46706,3 & 11495,2 & 125987,3 & 37125,4 & 295 \\
\hline $\mathrm{C}_{0}$ & - & - & - & - & 2234,6 & 114,1 & 2234,6 & 114,1 & 51 \\
\hline $\mathrm{C}_{1}$ & - & - & 668,5 & 78,8 & 28308,5 & 2703,2 & 28977,0 & 2782,0 & 96 \\
\hline $\mathrm{C}_{2}$ & 4808,2 & 1720,5 & 23314,5 & 6383,9 & 11747,8 & 2092,7 & 39870,5 & 10197,1 & 256 \\
\hline $\mathrm{C}_{3}$ & 3981,4 & 900,1 & 5721,7 & 1371,7 & 3762,5 & 663,5 & 13465,6 & 2935,3 & 218 \\
\hline $\mathrm{C}_{4}$ & 3539,6 & 674,1 & 3422,0 & 632,5 & 2080,7 & 406,6 & 9042,3 & 1713,2 & 189 \\
\hline $\mathrm{C}_{5}$ & 274,2 & 76,5 & 447,7 & 88,0 & 141,4 & 26,1 & 863,3 & 190,6 & 221 \\
\hline Разом & 12603,4 & 3371,2 & 33574,4 & 8554,9 & 48275,5 & 6006,2 & 94453,3 & 17932,3 & 190 \\
\hline $\mathrm{D}_{0}$ & - & - & - & - & 1025,9 & 70,4 & 1025,9 & 70,4 & 69 \\
\hline $\mathrm{D}_{1}$ & - & - & 12234,2 & 2294,4 & 39920,8 & 5362,1 & 52155,0 & 7656,5 & 147 \\
\hline $\mathrm{D}_{2}$ & 156,4 & 36,0 & 98072,4 & 25137,4 & 30569,3 & 5949,3 & 128798,1 & 31122,7 & 242 \\
\hline $\mathrm{D}_{3}$ & 409,3 & 106,3 & 3641,1 & 874,4 & 8166,3 & 1676,3 & 12216,7 & 2657,0 & 217 \\
\hline $\mathrm{D}_{4}$ & 24,5 & 3,9 & 2128,6 & 407,7 & 923,8 & 211,5 & 3076,9 & 623,1 & 203 \\
\hline $\mathrm{D}_{5}$ & - & - & 491,2 & 99,8 & 236,6 & 67,9 & 727,8 & 167,7 & 230 \\
\hline Разом & 590,2 & 146,2 & 116567,5 & 28813,7 & 80842,7 & 13337,5 & 198000,4 & 42297,4 & 214 \\
\hline Всього & 61943,8 & $\mathbf{1 8 7 4 7 , 1}$ & 209302,0 & 55428,2 & 211962,2 & 37624,6 & 483208,0 & 111799,9 & 231 \\
\hline
\end{tabular}

Табл. 2. Розподіл рекреаційно-оздоровчих лісів Лівобережної України залежно від їх розташування та типів умов місцезростання

\begin{tabular}{|c|c|c|c|c|c|c|c|c|}
\hline \multirow[t]{2}{*}{ ТУМ } & \multicolumn{2}{|c|}{$\begin{array}{c}\text { Лісові ділянки у межах } \\
\text { міст, селищ та інших на- } \\
\text { селених пунктів }\end{array}$} & \multicolumn{2}{|c|}{$\begin{array}{c}\text { Лісові ділянки у межах по- } \\
\text { ясів зон санітарної охорони } \\
\text { водних об'єктів у лісах }\end{array}$} & \multicolumn{2}{|c|}{$\begin{array}{l}\text { Лісові ділянки зелених зон } \\
\text { навколо населених пунктів }\end{array}$} & \multicolumn{2}{|c|}{$\begin{array}{c}\text { Лісові ділянки поза межами } \\
\text { лісів зелених зон }\end{array}$} \\
\hline & площа, га & запас, тис. $\mathrm{m}^{3}$ & площа, га & запас, тис. м $^{3}$ & площа, га & запас, тис. м $^{3}$ & площа, га & 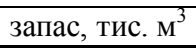 \\
\hline $\mathrm{A}_{0}$ & 16,2 & 1,9 & 20,9 & 1,6 & 11,8 & 0,9 & 136,0 & 16,8 \\
\hline $\mathrm{A}_{1}$ & 859,1 & 104,1 & 2406,1 & 329,0 & 2496,0 & 456,5 & 8680,5 & 1395,3 \\
\hline $\mathrm{A}_{2}$ & 881,8 & 190,0 & 6081,6 & 1273,3 & 13298,9 & 3681,7 & 29496,9 & 6948,0 \\
\hline $\mathrm{A}_{3}$ & & & 44,0 & 5,9 & 38,7 & 7,5 & 297,1 & 32,2 \\
\hline $\mathrm{A}_{4}$ & & & & & & & 1,4 & 0,1 \\
\hline Разом & 1757,1 & 296,0 & 8552,6 & 1609,8 & 15845,4 & 4146,6 & 38611,9 & 8392,4 \\
\hline $\mathrm{B}_{0}$ & & & & & 59,8 & 3,3 & & \\
\hline $\mathrm{B}_{1}$ & 428,7 & 64,0 & 1556,2 & 359,0 & 3184,9 & 571,5 & 4657,8 & 1124,8 \\
\hline $\mathrm{B}_{2}$ & 1907,7 & 557,0 & 7927,1 & 2084,3 & 33142,9 & 10786,6 & 62108,7 & 19266,5 \\
\hline $\mathrm{B}_{3}$ & 172,1 & 28,6 & 746,5 & 110,0 & 4219,0 & 911,4 & 5334,5 & 1179,9 \\
\hline $\mathrm{B}_{4}$ & 1,1 & 0,1 & 15,6 & 2,5 & 284,5 & 40,3 & 205,3 & 30,7 \\
\hline $\mathrm{B}_{5}$ & & & & & 7,2 & 0,3 & 27,3 & 4,7 \\
\hline Разом & 2509,6 & 649,7 & 10245,4 & 2555,9 & 40898,3 & 12313,4 & 72333,6 & 21606,6 \\
\hline $\mathrm{C}_{0}$ & 141,4 & 8,0 & 171,4 & 9,4 & 1921,8 & 96,8 & & \\
\hline $\mathrm{C}_{1}$ & 10119,3 & 1085,6 & 2375,5 & 241,0 & 14427,9 & 1248,1 & 2054,3 & 207,4 \\
\hline $\mathrm{C}_{2}$ & 2402,4 & 427,0 & 2787,7 & 631,8 & 11475,3 & 2912,7 & 23205,1 & 6225,7 \\
\hline $\mathrm{C}_{3}$ & 499,2 & 107,9 & 1152,8 & 224,2 & 3086,0 & 740,6 & 8727,6 & 1862,6 \\
\hline $\mathrm{C}_{4}$ & 215,7 & 49,2 & 575,5 & 130,0 & 2577,5 & 624,7 & 5673,6 & 909,4 \\
\hline $\mathrm{C}_{5}$ & 13,1 & 5,9 & 29,4 & 6,1 & 387,1 & 99,0 & 433,7 & 79,7 \\
\hline Разом & 13391,1 & 1683,6 & 7092,3 & 1242,5 & 33875,6 & 5721,9 & 40094,3 & 9284,8 \\
\hline $\mathrm{D}_{0}$ & 56,1 & 4,1 & 78,0 & 5,7 & 834,0 & 55,7 & 57,8 & 4,9 \\
\hline $\mathrm{D}_{1}$ & 16185,6 & 2098,4 & 3013,5 & 389,6 & 24218,9 & 3861,0 & 8737,0 & 1307,5 \\
\hline $\mathrm{D}_{2}$ & 8483,9 & 1723,6 & 7849,1 & 1417,8 & 69591,8 & 16512,9 & 42745,0 & 11441,3 \\
\hline $\mathrm{D}_{3}$ & 423,5 & 102,2 & 2272,9 & 448,9 & 3411,7 & 796,3 & 6108,6 & 1309,4 \\
\hline $\mathrm{D}_{4}$ & 54,6 & 9,3 & 176,7 & 42,1 & 494,7 & 124,1 & 2350,9 & 447,5 \\
\hline $\mathrm{D}_{5}$ & 7,0 & 1,5 & 16,3 & 4,0 & 151,0 & 42,1 & 553,5 & 120,0 \\
\hline Разом & 25210,7 & 3939,1 & 13406,5 & 2308,1 & 98702,1 & 21392,1 & 60552,8 & 14630,6 \\
\hline Всього & 42868,5 & 6568,4 & 39296,8 & 7716,2 & 189321,4 & 43574,0 & 211593,0 & 53914,4 \\
\hline
\end{tabular}


Аналізуючи насадження в межах міст, селищ та інших населених пунктів зазначимо, що більша частина їх росте в умовах груд - 58,8 \% і характеризуються при цьому найбільшим загальним запасом - 59,9\%. Найменшу площу і найменший загальний запас мають насадження в умовах борів - 4,1 та 4,5\% відповідно. Найбільший середній запас деревостанів характерний для лісових ділянок в умовах борів - $259 \mathrm{~m}^{3} \cdot \mathrm{ra}^{-1}$, а найменший в умовах сугруд $-126 \mathrm{~m}^{3} \cdot \mathrm{ra}^{-1}$. Серед гігротопів переважають сухі умови: у борах - 2,0 \%; у субоpax $-1,0 \%$; у сугрудах $-23,6 \%$; у грудах $-37,8 \%$. Частка лісових ділянок у мокрих умовах становить $<0,1 \%$, що $\epsilon$ найменшим показником серед насаджень урбанізованих територій (див. табл. 2).

Груди займають панівне становище і серед деревостанів у межах поясів зон санітарної охорони водних об'єктів у лісах як за площею, так і за загальним запасом - 34, 1 і 29,9 \% відповідно. За площею найменш поширені насадження в умовах сугрудів, де їх частка становить 18,0 \% за площею і 16,1 \% за загальним запасом. Найбільший середній запас на 1 га притаманний насадженням в умовах борів $-249 \mathrm{~m}^{3} \cdot \mathrm{ra}^{-1}$, а найменший - в умовах сугрудів $\left(175 \mathrm{~m}^{3} \cdot \mathrm{ra}^{-1}\right)$. Щодо умов зволоження, то тут переважають деревостани у свіжих умовах: у боpax $-15,5 \%$; у суборах - 20,2 \%; у сугрудах $-7,1 \%$; у грудах $-20,0 \%$, а найменше їх росте в мокрих умовах.

Насадження у межах округів санітарної охорони лікувально-оздоровчих територій і курортів ростуть тільки в умовах свіжого груду на площі 128,3 га, із загальним запасом - 26,9 тис. $\mathrm{m}^{3}$ та середнім запасом $420 \mathrm{~m}^{3} \cdot \mathrm{ra}^{-1}$. Панівним трофотопом лісових ділянок зелених зон навколо населених пунктів як за площею, так i за загальним запасом є груди - 52,2 і 49,1 \% відповідно. Найменшу площу займають насадження в умовах борів - 8,3 \%. Найбільший середній запас притаманний деревостанам в умовах суборів $\left(301 \mathrm{~m}^{3} \cdot \mathrm{ra}^{-1}\right)$, а найменший в умовах сугрудів $\left(169 \mathrm{~m}^{3} \cdot \mathrm{ra}^{-1}\right)$. За гігротопами перевагу мають насадження у свіжих умовах: у борах - 7,0 \%; у суборах - $17,5 \%$; у сугрудах $-6,1 \%$; у дібровах $36,8 \%$, а найменше вони поширені в мокрих умовах: у борах $-0,0 \%$; у суборах $-<0,1 \%$; у сугрудах $-0,2 \%$; у грудах $-0,1 \%$.

Найбільша частка насаджень поза межами лісів зелених зон ростуть в умовах суборів - 34,2 \% і мають відповідно найбільший загальний запас - 40,1\%. Найменша частка насаджень зосереджена в умовах борів - 18,2 \% за площею і $15,6 \%$ за загальним запасом. За вологістю найбільшу частку площі займають лісові ділянки у свіжих умовах: у борах - 13,9\%; у суборах $29,4 \%$; у сугрудах - $11,0 \%$; у грудах $-20,3 \%$, а найменшу - в дуже сухих умовах: у борах $-0,1 \%$; у суборах $-0,0 \%$; у сугрудах $-0,0 \%$; у грудах $-<0,1 \%$.

\section{Висновки}

Внаслідок проведеного дослідження вивчено екологічне різноманіття рекреаційно-оздоровчих лісів Лівобережної України за природними зонами та залежно від ïx розташування (підкатегорій), що дало змогу встановити серед них панівні трофотопи та гігротопи. За результатами дослідження мозна зробити такі основні висновки.

1. Встановлено, що більшість насаджень у рекреаційно-оздоровчих лісах ростуть в умовах груд та віддають перевагу свіжим гігротопам. Зазначимо, що для природних зон ситуація є дещо іншою. Так, у Лівобережному Поліссі за трофністю переважають умови борів, а за зволоженням - свіжі умови. У Лівобережному Лісостепу найбільші площі займають насадження, що ростуть в умовах свіжих груд. Насадження Лівобережного Степу віддають перевагу також багатим та зволоженим грунтам.

2. Виявлені особливості поширення насаджень за типами умов місцезростання мають бути основою для планування та здійснення відповідних лісогосподарських заходів, що дасть змогу в подальшому вирощувати та формувати високопродуктивні, біологічно стійкі, довговічні та високодекоративні насадження, які ефективно виконуватимуть важливі екологічні функції.

\section{References}

1. Bondarenko, V. D., \& Furdychko, O. I. (1994). Forest and recreation in the forest. Lviv: Svit. [In Ukranian].

2. Gensiruk, S. A. (1979). Rational nature management. Moscow: Lesnaia promyshlennost. [In Russian].

3. Modern problems of forest typology. (1985). Moscow: Nauka. AN SSSR. [In Russian].

4. Musienko, S. I., Bondarenko, V. V., Tarnopilska, O. M., Rumiantsev, M. N., Kobets, O. V., \& Lukyanets, V. A. (2020). State of recreational and health-improving forests in Kharkiv Region. Kharkiv: Forestry and Forest Melioration. https://doi.org/10.33220/1026-3365.136.2020.12

5. Musienko, S., Lyalin, O., Tkach, L., Babenko, V., \& Sułkowska, M. (2018). Characteristics and current situation of urban forests in Kharkiv region. Folia Forestalia Polonica, Series A - Forestry. https://doi.org/10.2478/ffp-2018-0017

6. Ostapenko, B. F., \& Tkach, V. P. (2002). Forest typology: Textbo$o k$. Kharkiv: KhNAU im. V. V. Dokuchayeva. [In Ukranian].

7. Pogrebnyak, P. S. (1963). General forestry. Moscow: Izdatelstvo selskokhozyajstvennoj literatury. [In Russian].

8. Resolution of Cabinet of Ministers of Ukraine. No 733 dated 16.05.2007 "Procedure for Dividing Forests into Categories and Allocation of Specially Protected Forest Areas". Retrieved from: https://zakon.rada.gov.ua/laws/show/733-2007-\%D0\%BF. (Accessed on 12 November 2020). [In Ukranian].

9. Vedmid, M. M., \& Raspopina, S. P. (2010). Assessment of forest vegetation potential of lands. Training course for students of the Ukrainian Center for Training, Retraining and Advanced Training of Forestry "Ukrcentrkadrylis". Boyarka: Vydavnychyj dim "Eko-inform". [In Ukranian].

S. I. Musienko, V. A. Lukyanets, V. V. Bondarenko, M. H. Rumiantsev, O. V. Kobets

Ukrainian Research Institute of Forestry and Forest Melioration named after G. M. Vysotsky, Kharkiv, Ukraine

\section{TYPOLOGICAL DIVERSITY OF RECREATIONAL AND HEALTH-IMPROVING FORESTS IN LEFT-BANK UKRAINE}

The paper presents the results of research on the typological diversity of recreational and health-improving forests of Left-Bank Ukraine. The typological diversity of recreational and health-improving forests of Left-Bank Ukraine in the context of natural areas and depending on their location (subcategories) was studied in the following areas: within cities, towns and other settlements; within the districts of sanitary protection of medical and health-improving areas and health resorts; within the zones of sanitary protection of 
water bodies in forests; in the forests of green areas around settlements; outside the forests of green areas. The predominant trophotopes and hygrotopes were found in the recreational and health-improving forests of Left-Bank Ukraine in terms of natural areas and depending on their location (subcategories). On the basis of the conducted researches we have revealed that the vast majority of plantations of recreational and health-improving forests of Left-Bank Ukraine grow in fertile site type conditions and prefer fresh hygrotopes. In Left-Bank Polissya, pine forest conditions predominate in terms of trophic and fresh considering moisture content. In the Left-Bank Forest-Steppe, the largest areas are occupied by forest plantations in the fertile site type conditions and fresh in terms of moisture content. The forest plantations of Left-Bank Steppe also prefer rich and moist soils. Therefore, the research results provide a basis for planning and conducting appropriate forestry activities in order to form highly productive, sustainable, durable, highly ornamental plantations that will effectively perform important environmental functions. The problem of increasing the species composition in recreational and health-improving forests is also relevant, as well as due to introduced tree and shrub species, in order to improve their environmenal and aesthetic properties.

Keywords: plantations; forest areas; natural areas; type of habitat conditions; trophotope; hygrotop. 